\title{
Anti-cancer Effect of Hot Water Extract from Mycelium in Germanium-enriched Cordyceps militaris
}

\author{
Jeong Su Choi ${ }^{1}$, Ji Hye Heo ${ }^{2}$, Dae Jin Kim ${ }^{1}$, Su Min Namkung ${ }^{1}$, Tae Bok Lee ${ }^{3}$, Min Woo Lee ${ }^{1,2}$, \\ Suhng Wook Kim ${ }^{1}$ \\ ${ }^{1}$ School of Health and Environmental Science, College of Health Sciences, Korea University, Seoul, Korea \\ ${ }^{2}$ Department of Clinical Laboratory Science, Donga College of Health, Yeongam, Korea \\ ${ }^{3}$ Department of Senior Healthcare, Graduate School, Eulji University, Daejeon, Korea
}

\section{게르마늄 농도를 증가 시킨 동충하초 균사체 열수 추출액의 항암효과}

\author{
최정수 ${ }^{1}$, 어지혜 $^{2}$, 김대진 $^{1}$, 남궁수민 $^{1}$, 이태복 ${ }^{3}$, 이민우 ${ }^{1,2}$, 김성욱 $^{1}$ \\ ${ }^{1}$ 고려대학교 보건과학대학 보건환경융합과학부, ${ }^{2}$ 동아보건대학교 임상병리과, ${ }^{3}$ 을지대학교 대학원 시니어헬스케어학과
}

\begin{abstract}
Cordyceps militaris has been used in traditional Chinese medicine owing to its anticancer and immunomodulatory activities. Germanium compounds have also been shown to be associated with many pharmacological functions, such as antimicrobial, antiviral, antitumor, antimutagenic, and immunomodulating effects. In this study, we examined the biological properties of hot water extract from mycelial liquid culture of germanium-enriched C. militaris (CMGe). CMGe displayed a concentration-dependent antiproliferation activity against four human cancer cell lines. The antiproliferative activity of CMGe was 2-4-fold lower than that of hot water extract from mycelial liquid culture in C. militaris (CM). However, $C M$ had a concentration-dependent cytotoxicity to human bone marrow-derived mesenchymal stem cells (MSCs). Contrastingly, CMGe did not cause any cellular damage to MSCS. MSCs cultured with CMGe displayed an increased proliferative activity with no cytotoxic effect. The oral administration of CMGe inhibited increased tumor volume and weight compared with the control group. CMGe has the potential to be used as an industrial product in medicinal foods as well as in pharmaceutical products.
\end{abstract}

Key words: Cordyceps militaris, Germanium, Cancer, Mesenchymal stem cell

This is an Open Access article distributed under the terms of the Creative Commons Attribution Non-Commercial Licens (http://creativecommons.org/licenses/by-nc/4.0) which permits unrestricted non-commercial use, distribution, and reproduction in any medium, provided the original work is properly cited.

Copyright $@ 2017$ The Korean Society for Clinical Laboratory Science. All rights reserved.

\author{
Corresponding author: Suhng Wook Kim \\ School of Health and Environmental Science, \\ College of Health Sciences, Korea University, \\ 145 Anam-ro, Seongbuk-gu, Seoul 02841 , \\ Korea \\ Tel: 82-2-3290-5686 \\ Fax: 82-2-940-2829 \\ E-mail:swkimkorea@korea.ac.kr \\ Co-Corresponding author: Min Woo Lee \\ Department of Clinical Laboratory Science, \\ Donga College of Health, 76-57 Yeongsan-ro, \\ Haksan-myeon, Yeongam 58439, Korea \\ Tel: 82-61-470-1606 \\ Fax: 82-61-470-1625 \\ E-mail: leemw@korea.ac.kr
}

Received: March 3, 2017 Revised $1^{\text {st: }}$ : April 24, 2017 Revised $2^{\text {nd }}$ : May 11, 2017

Revised 3 $3^{\text {rd: }}$ May 11, 2017

Accepted: May 11, 2017

\section{INTRODUCTION}

Germanium (Ge) is a trace element found in almost all nutrients, animals and plants [1,2]. Many studies have reported that germanium compounds have pharmacological functions such as antimicrobial [3], antiviral [4], antitumor [5-9], antimutagenic [6,10-12], and immunomodulating effects [13-16]. The biological activity of Ge depends on its chemical form. In general, inorganic germanium compounds, such as $\mathrm{GeO}_{2}$ and $\mathrm{GeCl}_{4}$, are toxic to the kidney and liver $[17,18]$, while organic Ge-containing compounds such as spirogermanium, germanium lactate citrate and carboxyethylgermanium sesquioxide exhibit diverse biological activity with mild toxicity $[14,19]$. 
Cordyceps militaris, a popular traditional Chinese medicinal mushroom, has been widely used as an herbal drug and a tonic food in areas of east Asia such as Korea, China, and Japan because of its various biological activities that include antitumor, antioxidation and immunomodulatory effects, which are generally attributed to the presence of bioactive entities that include adenosine, cordycepin and exopolysaccharides [20-24].

Mushrooms are effective in absorbing and accumulating trace elements from substrates, making them potentially useful in the production of mineral-enriched food and nutritional supplements. Recently, many investigators have prepared trace element-concentrated mushrooms to enhance biological activity and to reduce toxicity of inorganic elements $[25,26]$. Theoretically, Ge-enrichment cultivation should increase the medicinal value of $C$. militaris and make it as a new Ge supplementation food, which possibly possesses even greater health benefits provided by this specific mushroom. However, to our knowledge, there are very few reports on Ge-enriched $C$. militaris. In this study, we examined the biological properties of hot water extract from mycelial liquid culture of Ge-enriched C. militaris.

\section{MATERIALS AND METHODS}

\section{Materials}

Germanium dioxide $\left(\mathrm{GeO}_{2}\right)$ was purchased from Sigma-Aldrich (Saint Louis, MO, USA). C. militaris was purchased from Korean Culture Center of Microorganisms (KCCM, Seoul, Korea). Commercially available human bone marrow-derived mesenchymal stem cells (MSCs) were purchased from Lonza.

\section{Cultivation and mycelial extraction of Ge-enriched C. militaris}

The stock culture of $C$. militaris was maintained on potato dextrose agar (PDA) slants and sub-cultured every month. C. militaris mycelia were transferred to the liquid PDA medium containing 500 ppm of $\mathrm{GeO}_{2}$ by punching out $6 \mathrm{~mm}$-diameter agar discs on PDA plates. The culture was incubated at $25^{\circ} \mathrm{C}$ on a rotary shaker for 21 days. A hot water extract of the Ge-enriched $C$. militaris was prepared by boiling the culture at $100^{\circ} \mathrm{C}$ for $5 \mathrm{~h}$. After centrifugation at 12,000 rpm for $10 \mathrm{~min}$, the supernatants was filtered using a $0.45 \mu \mathrm{m}$ membrane filter, freeze-dried and used for experiments. A hot water extract of the Ge-enriched $C$. militaris contained 219 ppm Ge.

\section{Cell cytotoxicity test}

A viability assay based on the conversion of 3-(4,5-dimethylthiazol-2-yl)-2,5-diphenyltetrazolium bromide (MTT) was performed to test cytotoxicity and cell viability based on the conversion of yellow tetrazolium salt to an insoluble purple formazan product. Four human cancer cell lines (Ramos, A549, HepG2 and CEM) and human bone marrow-derived mesenchymal stem cells (MSCs) were grown in wells of a 96-well plate supplemented with culture medium. Cells were treated with hot water extract from mycelial liquid culture of the $C$. militaris $(\mathrm{CM})$ or with hot water extract from mycelial liquid culture of the Ge-enriched C. militaris (CMGe) for $48 \mathrm{~h}$, after which MTT solution was added and cells were incubated for $2 \mathrm{~h}$. After the supernatant was eliminated and dimethylsulfoxide was added to each well to dissolve the formazan, the absorbance at $570 \mathrm{~nm}$ was measured with a scanning multi-well spectrophotometer.

\section{Human tumor xenografts in nude mice}

Specific-pathogen-free BALB/c-nu female mice (SLC, Hamamatsu, Japan), 5.8 weeks old and weighing from 15.5 to $16.5 \mathrm{~g}$, were kept in an autoclaved cage to avoid contact with pathogens. All mice were adapted to the sterile basic supplementary diet and acclimatized to laboratory conditions for 10 days before use. To establish human tumors in mice, U87MG cells were cultured in RPMI-1640 medium containing 10\% heat-activated fetal bovine serum in a humidified atmosphere of $5 \% \mathrm{CO}_{2}$ at $37^{\circ} \mathrm{C}$. The cells were then detached by trypsinization, washed, and resuspended in phosphate buffered saline (PBS). The mice were randomly assigned to three groups ( $\mathrm{N}=5$ per group), all of which were subcutaneously 
inoculated with $0.1 \mathrm{~mL}$ of U87MG cells $\left(3 \times 10^{7}\right.$ cells $\left./ \mathrm{mL}\right)$ in the right flank. After 14 days postinoculation, the mice in the first group as a negative control were treated with $0.1 \mathrm{~mL}$ of PBS once per day by oral gavage, and the second and third groups were treated with CM and CMGe at dose of $150 \mathrm{mg} / \mathrm{kg} /$ day in $0.1 \mathrm{~mL}$ of PBS for 7 days. The volume of tumors was measured every day with a Vernier caliper. After treatment for 7 days, the mice were euthanized, and all tumors were removed and weighed.

\section{Statistical analysis}

All data in figure were expressed as mean and standard deviation. MTT assay data were calculated on three independent experiments. Data on volume and weight of the tumors were obtained from 5 mice in each group. SPSS software package (SPSS, Version 12.0, Chicago, USA) was used for statistical analysis, the results were estimated by one-way ANOVA with Tukey post-test in order to make a comparison of multiple groups. In this study, the threshold of significance was $p<0.05$.

\section{RESULTS}

\section{Antiproliferation activity of CMGe against cancer cell lines}

The antiproliferation activity induced by hot water extract from mycelial liquid culture of Ge-enriched Cordyceps militaris (CMGe) was investigated in four human cancer cell lines using the MTT assay. All tested cells were treated with CMGe at various concentrations for $48 \mathrm{~h}$. As shown in Figure 1 and Figure 2, the number of metabolically active cells decreased when treated with the samples at various concentrations for $48 \mathrm{~h}$ as compared to the untreated cells. The decrease in cell survival was more evident with increasing concentrations of $\mathrm{CMGe}$. CMGe had the highest antiproliferation activity against human $\mathrm{T}$
A

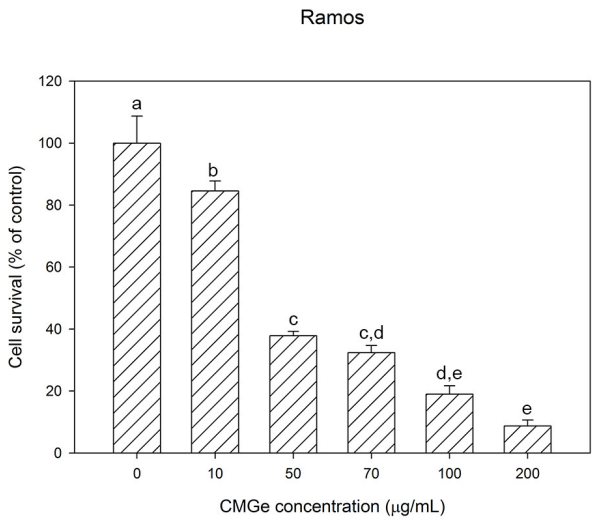

C

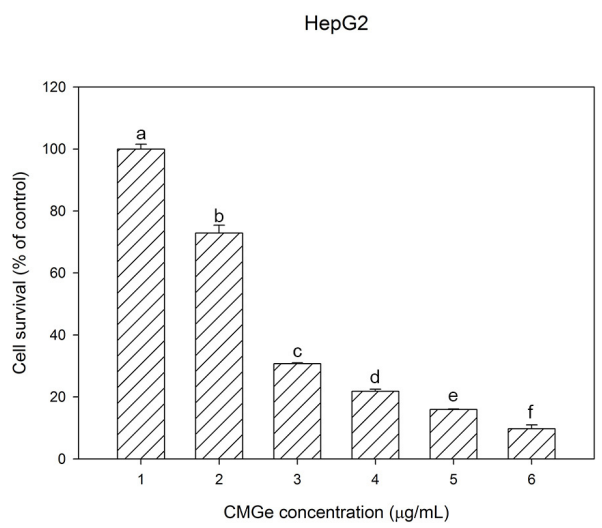

B

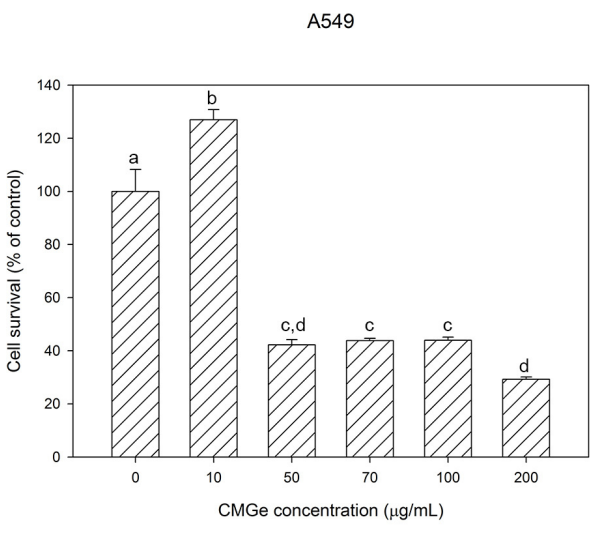

D

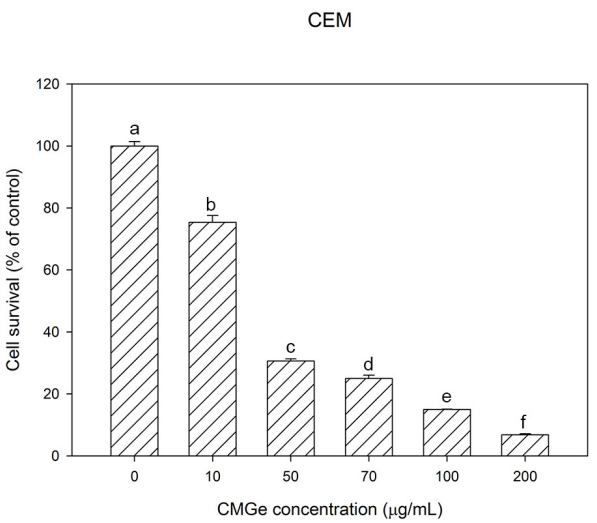

Figure 1. Effects of $C M G e$ on cancer cell growth. (A) Ramos, (B) A549, (C) HepG2 and (D) CEM cells were used for MTT assay. Means that have a different superscript letter $(a \sim f)$ differ significantly with each other at $p<0.05$. 
Ramos (CMGe)
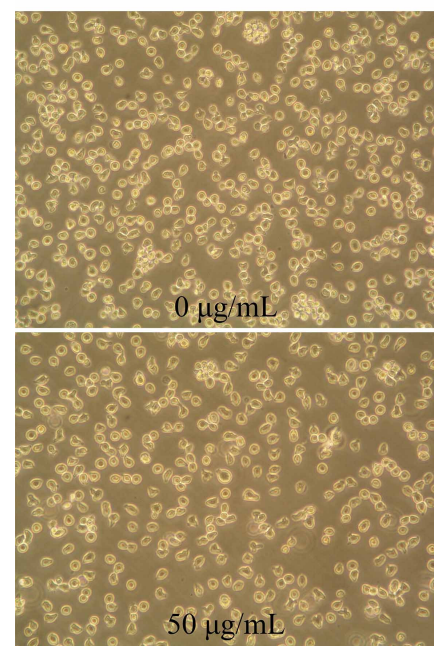

$100 \mu \mathrm{g} / \mathrm{mL}$
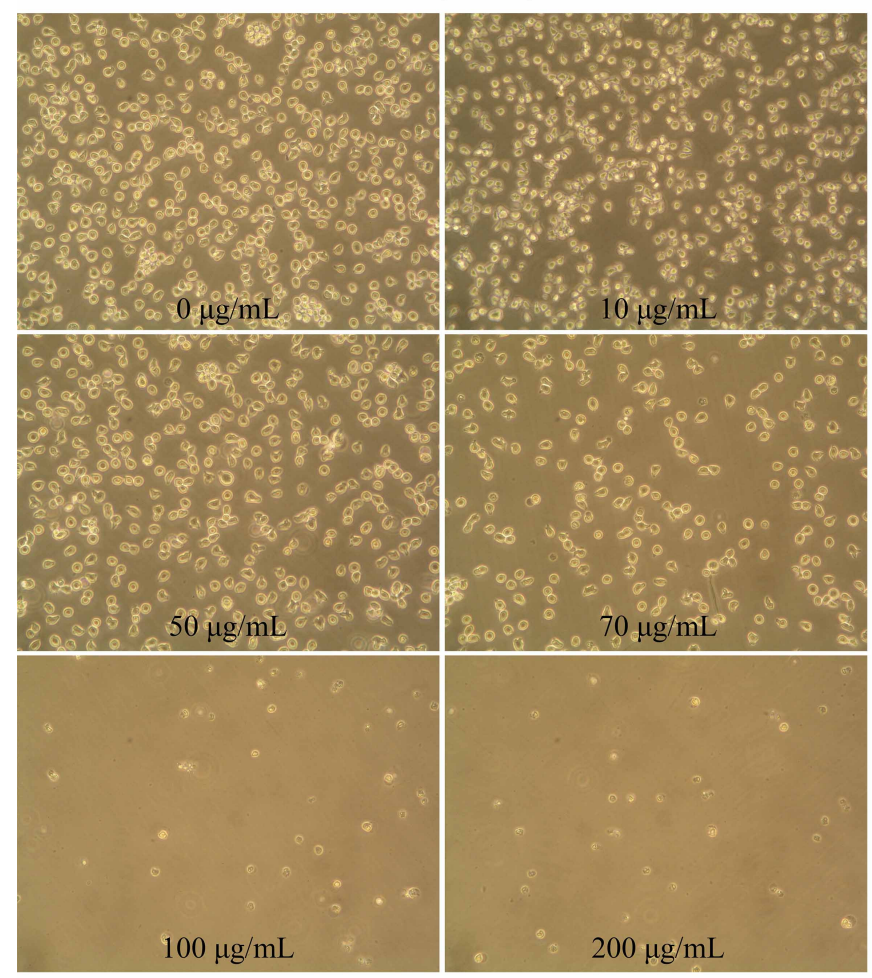

HepG2 (CMGe)
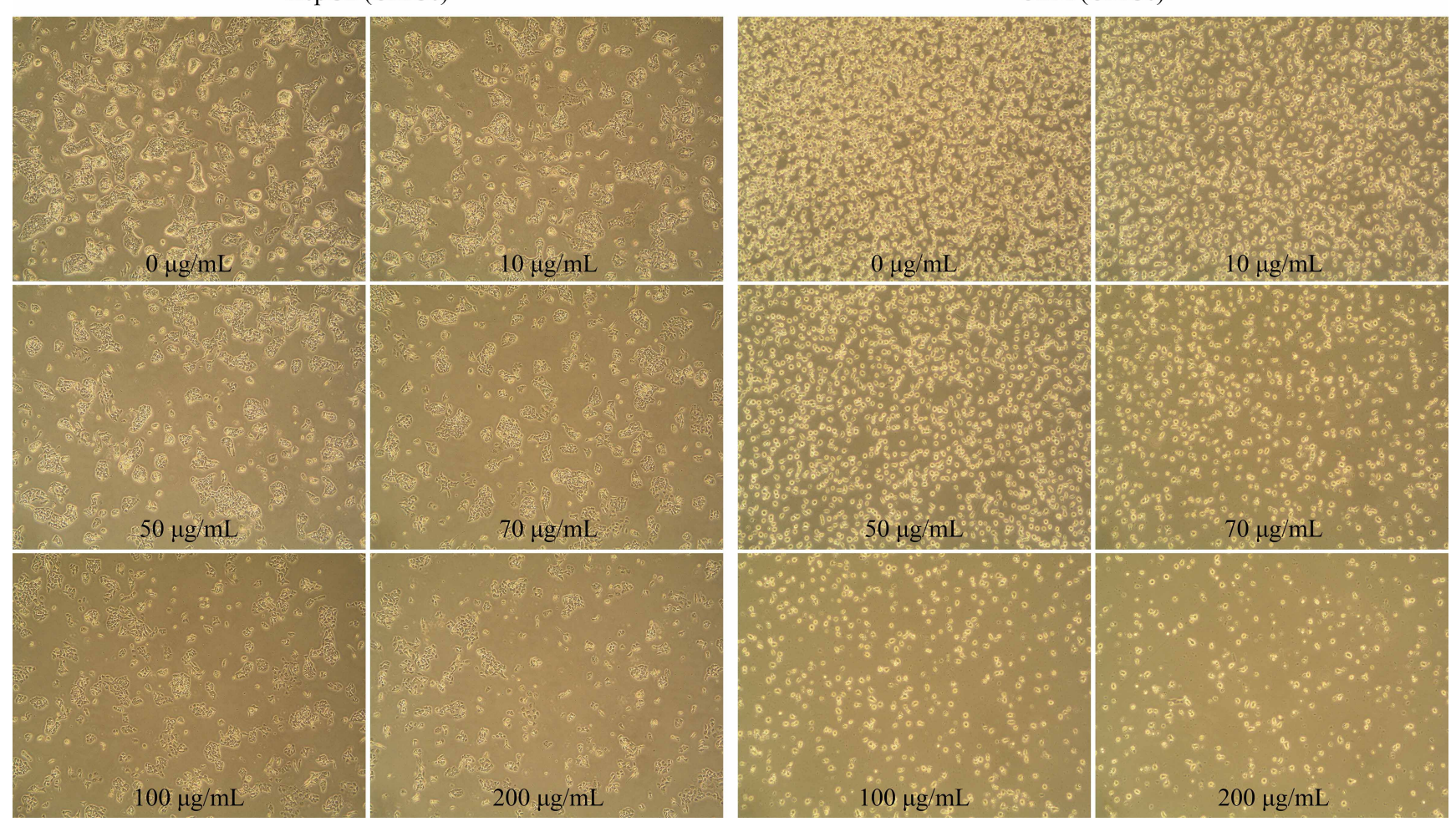

Figure 2. Cancer cell growth morphology at after CMGe treated for $48 \mathrm{~h}$. The cancer cells were photographed using optical microscope at $100 \times$. 
lymphoblastoid cell line (CEM), whereas the inhibitory activity against the human lung cancer cell line (A549) was low.

\section{Antiproliferation activity of $\mathrm{CM}$ against cancer cell lines}

In order to evaluate the antiproliferation activity of hot water extract from mycelial liquid culture of $C$. militaris (CM), MTT assay and morphological analysis was performed on the same cancer cell lines as in the above experiment. Experimental conditions of $\mathrm{CM}$ for cancer cell lines were designed in the equivalent manner as for $\mathrm{CMGe}$ treatment. The antiproliferative activity of $\mathrm{CM}$ was found to increase in a concentration-dependent and 24-fold higher than CMGe (Figure 3 and Figure 4). CM had the highest antiproliferation activity against human hepatocarcinoma HepG2 cells, whereas the inhibitory activity against the human lung cancer cell line (A549) was low.

\section{Antiproliferation activity of $C M$ and $C M G e$ against mesenchymal stem cells}

When the MTT assay was performed on human bone marrow-derived mesenchymal stem cells (MSCs) treated with a variety of concentrations of CM, MSC viability was reduced compared to controls. Treatment with 50, 70, 100 and $200 \mu \mathrm{g} / \mathrm{mL}$ of $\mathrm{CM}$ caused a significant decline of viable cells (Figure 5). In contrast to CM, which inhibited MSC proliferation, CMGe did not cause any observable cellular damage to MSCs. Furthermore, proliferation of MSCs was increased at concentrations including 50, 70 and 100 $\mu \mathrm{g} / \mathrm{mL}$ of CMGe. Specifically, proliferation of MSCs was elevated up to 1.8-fold of the control value when treated with $50 \mu \mathrm{g} / \mathrm{mL}$ of CMGe (Figure 5). There were slight decreases in viability of MSCs when treated with CMGe concentrations exceeding $200 \mu \mathrm{g} / \mathrm{mL}$. These findings indicate that CMGe can enhance proliferation of MSCs
A

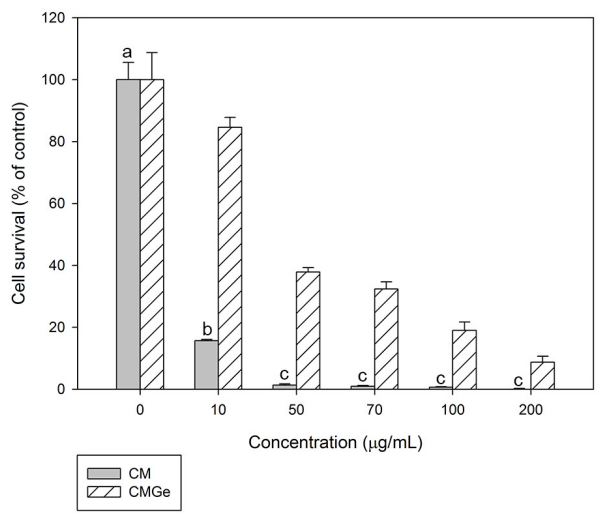

C

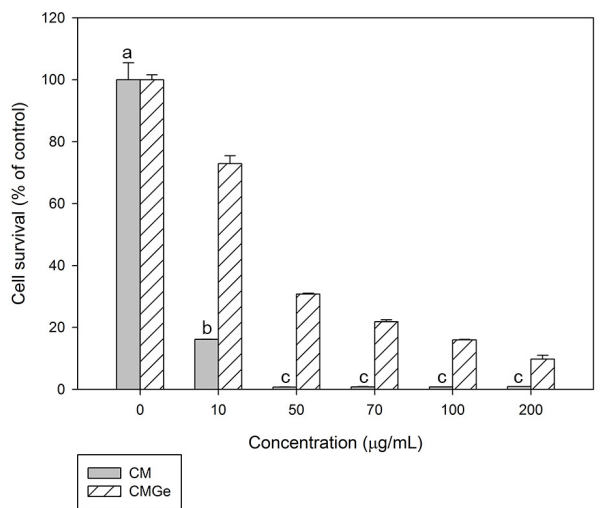

B

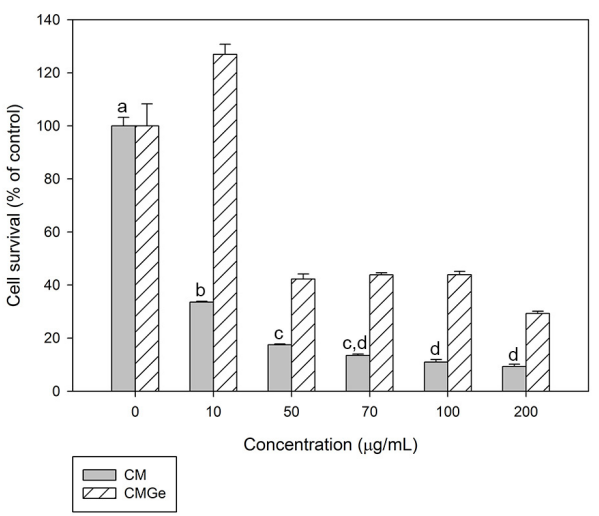

D

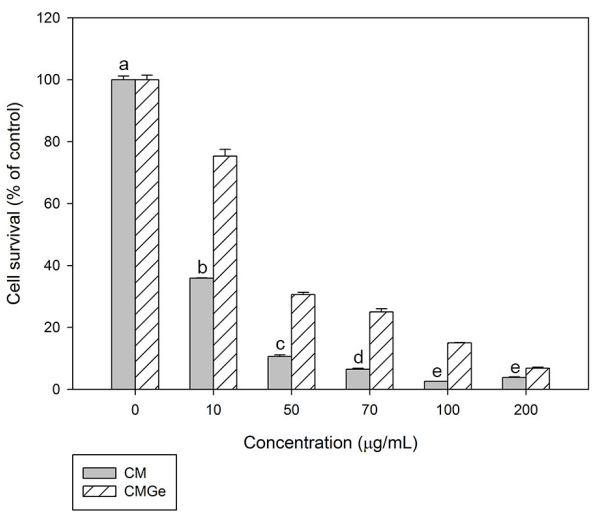

Figure 3. Comparison of effect of $\mathrm{CM}$ and $C M G e$ on the proliferation of cancer cell. (A) Ramos, (B) A549, (C) HepG2 and (D) CEM cells were used for MTT assay. Means that have a different superscript letter (a e) differ significantly with each other at $p<0.05$. 
Ramos (CM)

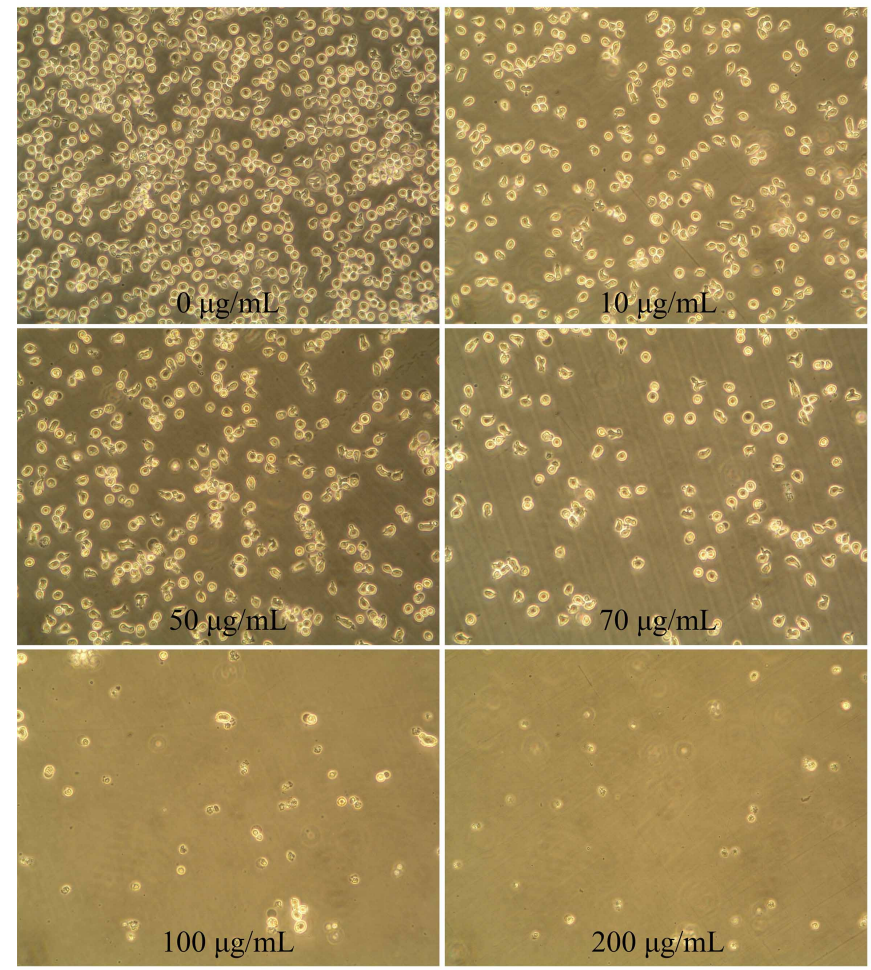

HepG2 (CM)

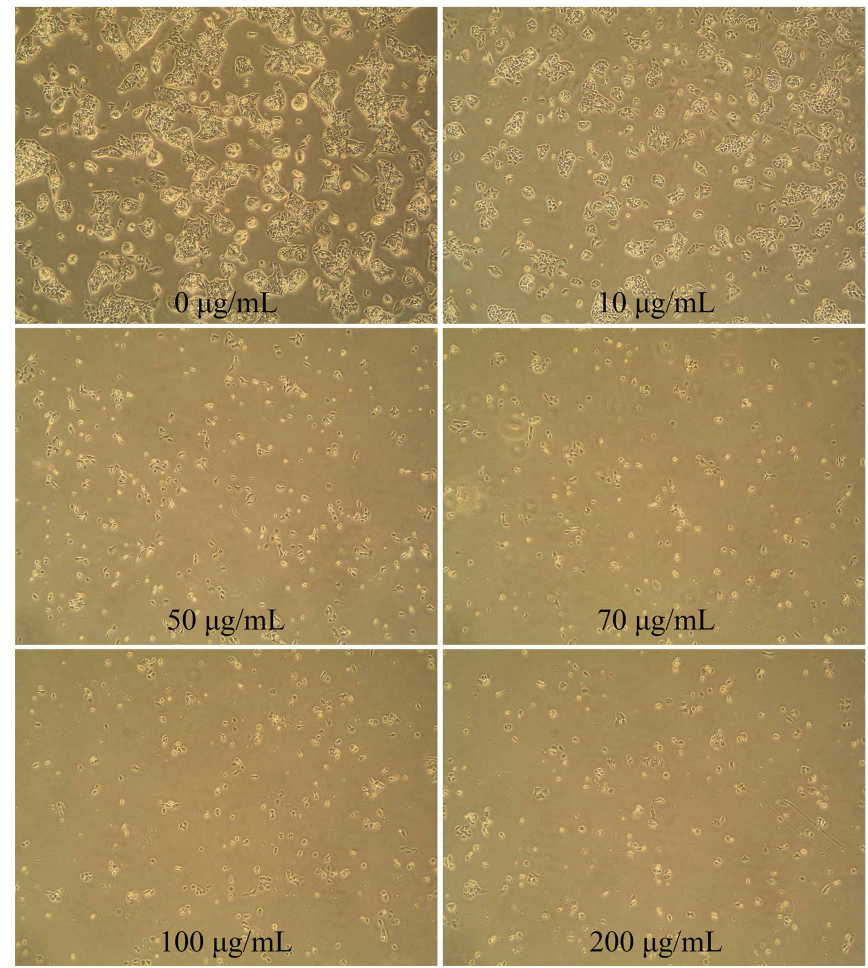

A549 (CM)

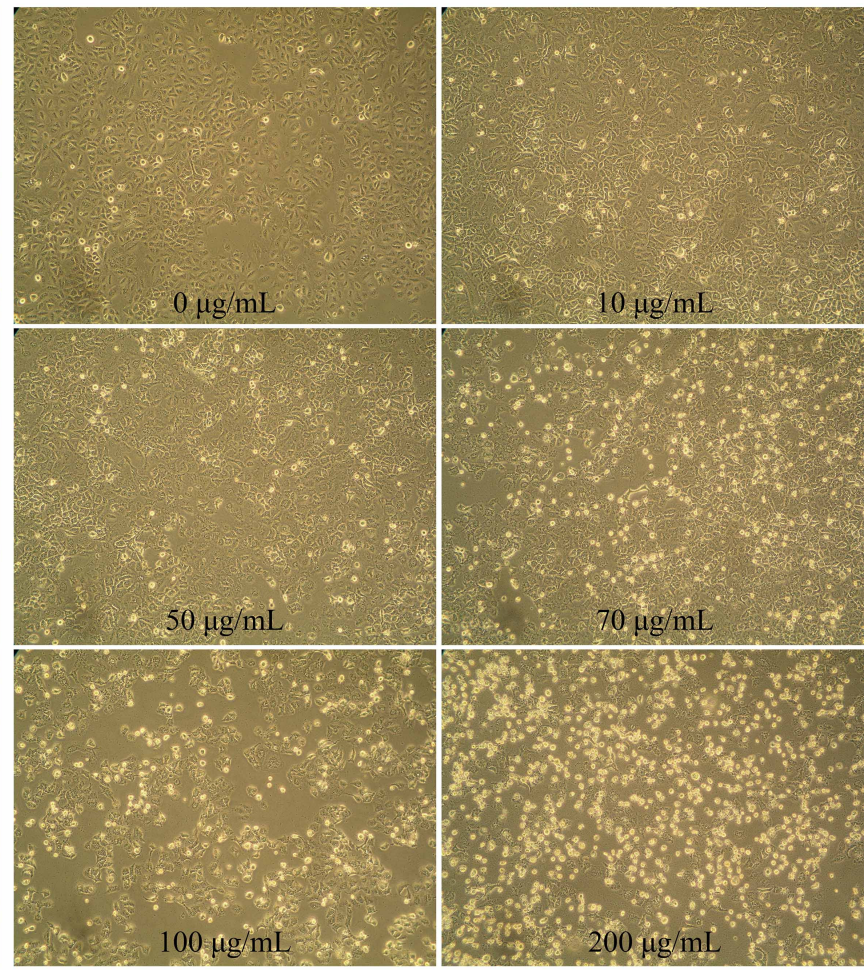

CEM (CM)

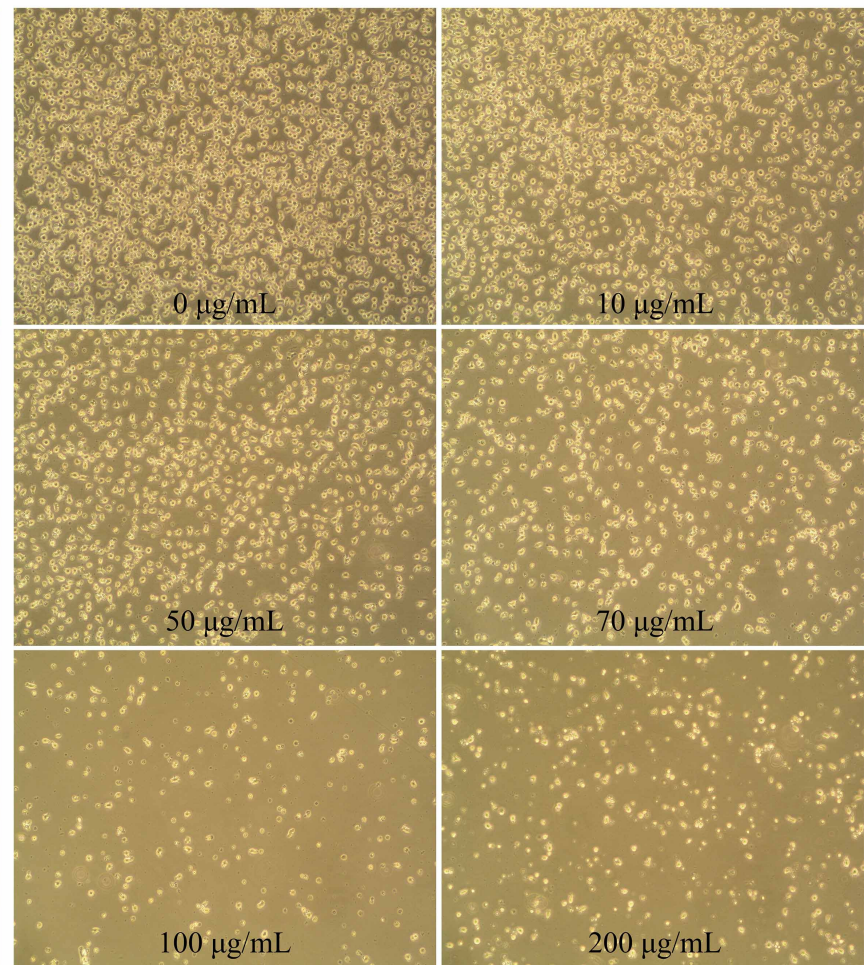

Figure 4. Cancer cell growth morphology at after CM treated for $48 \mathrm{~h}$. The cancer cells were photographed using optical microscope at $100 \times$. 

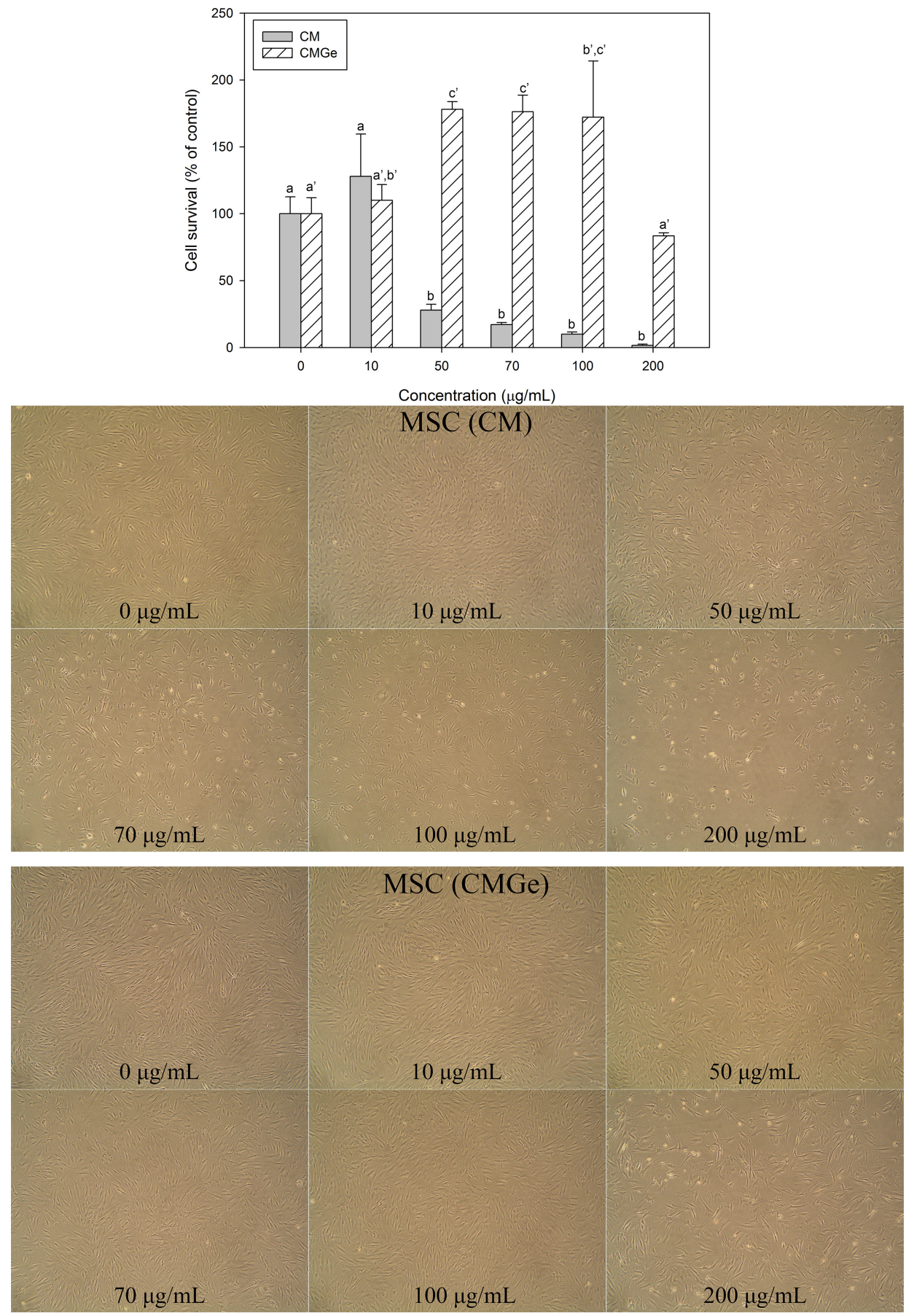

Figure 5. Comparison of effect of CM and $\mathrm{CMGe}$ effect on the proliferation of MSCs. human bone marrow-derived mesenchymal stem cells (MSCs) were used for MTT assay. Means that have a different superscript letter $(a \sim b, a$; c') differ significantly with each other at $p<0.05$. MSCs were photographed using optical microscope at $100 \times$.

without being cytotoxic.

\section{Antitumor activity of $\mathrm{CM}$ and $\mathrm{CMGe}$ on tumor xenograft in vivo}

Finally, to investigate whether CMGe inhibits the in vivo growth of tumor mass in mice, U87MG human neuronal glioblastoma cells were inoculated into nude mice. CM and CMGe were then orally administered to support anticancer activity against human neuronal tumor xenografts in vivo. The observation data for averages of the volume and weight of human tumor xenografts in the negative control and the $\mathrm{CM}$ or $\mathrm{CMGe}$-treated groups are 

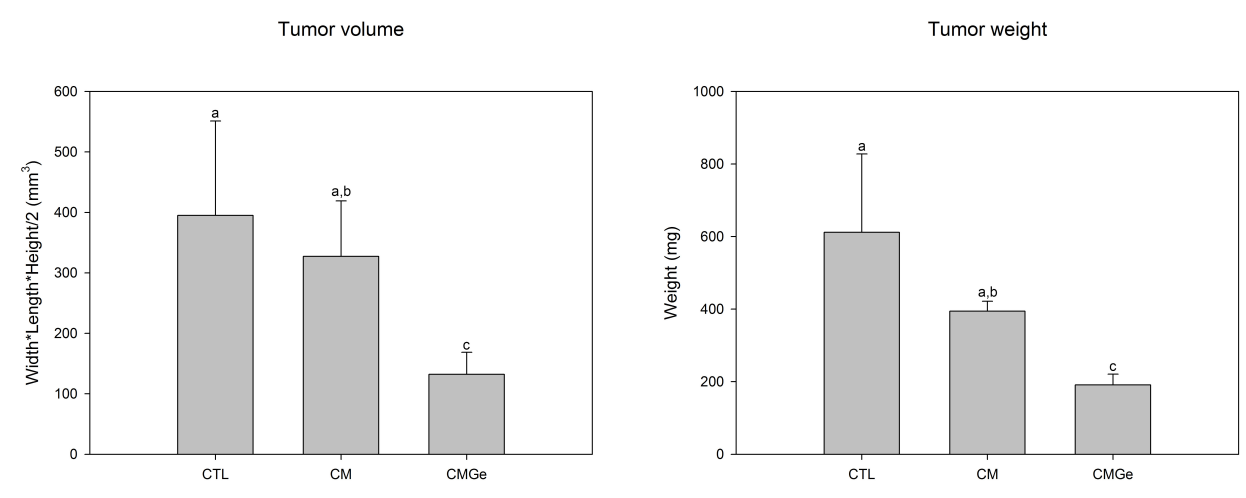

Figure 6. Effects of $\mathrm{CM}$ and $\mathrm{CMGe}$ on tumor volume and tumor mass. Vehicle control (VC) used as a negative control. Means that have a different superscript letter $(a \sim c)$ differ significantly with each other at $p<0.05$.

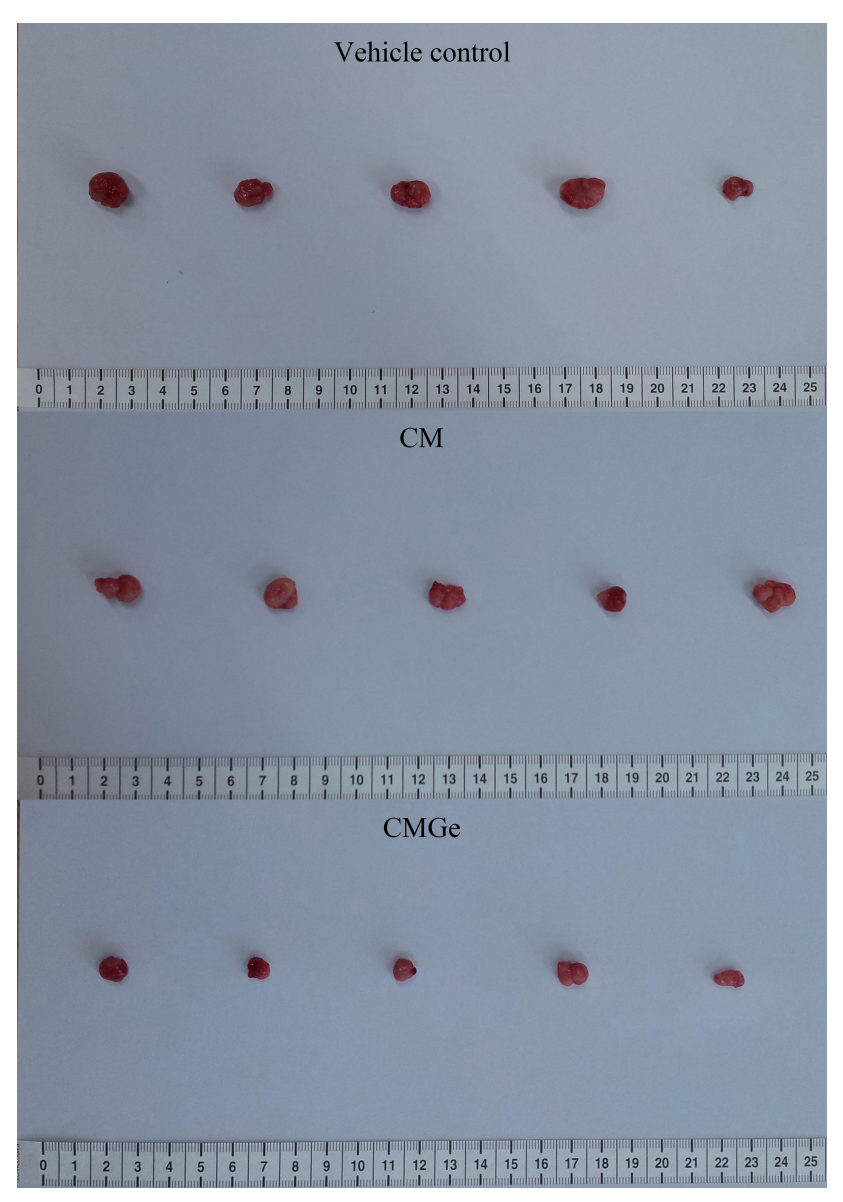

Figure 7. Photographs of U87MG tumors.

presented in Figure 6. The oral administration of $\mathrm{CM}$ and CMGe slightly inhibited the tumor growth compared to the control group. The average of the weight of human tumor xenografts in the CMGe-treated group was lower than those in the negative control group and CM-treated group. Figure 7 displayed visual inspection against U87MG tumors each of groups. The result that the tumors of
CMGe-treated group were the smallest was also easy to observe with the unaided eyes.

\section{DISCUSSION}

C. militaris is expected to gradually increase role as an anti-cancer agent in the pharmacognosy sector. In this regard, various scientific endeavors are needed to validate the efficacy of $C$. militaris [20]. According to our experimental results, the hot water extract from mycelial liquid culture of germanium-enriched C. militaris (CMGe) displayed a concentration-dependent antiproliferation activity against four human cancer cell lines. Human bone marrow-derived mesenchymal stem cells cultured with CMGe displayed increased proliferative activity with no cytotoxic effect.

Antiproliferative activity of CMGe was 2 4-fold lower than that of hot water extract from mycelial liquid culture of C. militaris (CM) indicating that the incorporation of Ge in Ge-enriched mycelia of $C$. militaris did not increase antiproliferative activities against human cancer cells. Although the antiproliferative activity of CM was higher than that of CMGe, CM showed a concentration-dependent cytotoxicity to normal control stem cells. The oral administration of CMGe inhibited increased tumor volume and weight compared to the control group.

This suggests that CMGe would be a more attractive industrial product for medicinal foods as well as pharmaceutical products. Since the hot water extraction process is very simple, CMGe can be mass-produced at low cost and can be used as an applicable and economical 
anticancer active product.

\section{요 약}

게르마늄 $(\mathrm{Ge})$ 은 거의 대부분의 영양분, 동물, 식물에서 발견 되는 미량원소로 많은 연구를 통해 항균성 항바이러스성 항종 양성 항돌연변이성 및 면역조절 효과를 지닌 것으로 알려져 있 다. 또한, 동충하초는 중국의 전통적인 약용 버섯으로 항종양성, 항산화성 및 면역조절 효과 등 다양한 생물학적 활성을 지니고 있으며 미량원소를 축적시키기 효과적인 것으로 알려져 있다. 이런 특성을 이용하여 본 연구는 게르마늄 농도를 증가시킨 동 충하초 $(\mathrm{CMGe})$ 의 열수 추출액을 얻어내고 그 생물학적 특성을 실험하였다. 네 가지 암세포주 Ramos, A549, HepG2, CEM와 $\mathrm{MSC}$ 에 대한 $\mathrm{CMGe}$ 의 세포독성을 MTT assay를 통해 확인한 결과, $\mathrm{CEM}$ 에서 항증식성이 가장 높고 $\mathrm{MSC}$ 에 대한 세포독성은 낮은 것으로 확인되었다. 마지막으로 누드마우스에 인간 신경 아교세포종(U87MG)을 이종이식하여 종양의 부피와 무게를 조사한 결과, $\mathrm{CMGe}$ 열수 추출액 처리군에서 종양 부피와 무게 의 감소를 확인할 수 있었다. 이런 결과는 $\mathrm{CMGe}$ 가 앞으로 의약 및 제약산업에 다양하게 적용될 수 있을 것으로 기대된다.

\section{Acknowledgements: None}

Funding: None

Conflict of interest: None

\section{REFERENCES}

1. Schroeder HA, Balassa JJ. Abnormal trace metals in man: Germanium. J Chronic Dis. 1967;20(4):211-224.

2. Schroeder HA, Balassa JJ. Arsenic, germanium, tin, and vanadium in mice: Effects on growth, survival and tissue levels. J Nutr. 1967;92(2):245-252.

3. Sijpesteijn A, Rijkens KF, van der Kerk GJ, Manten A. Antimicrobial activity of organogermanium derivatives. Nature. 1964;201:736.

4. Aso H, Suzuki F, Ebina T, Ishida N. Antiviral activity of carboxyethylgermanium sesquioxide (Ge-132) in mice infected with influenza virus. J Biol Response Mod. 1989;8(2):180-189.

5. Brutkiewicz RR, Suzuki F. Biological activities and antitumor mechanism of an immunopotentiating organogermanium compound, Ge-132 (review). In Vivo. 1987;1(4):189-203.

6. Gerber GB, Léonard A. Mutagenicity, carcinogenicity and teratogenicity of germanium compounds. Mutat Res. 1997;387(3): 141-146.

7. Jao SW, Lee W, Ho YS. Effect of germanium on 1,2-dimethylhydrazine-induced intestinal cancer in rats. Dis Colon Rectum.
1990;33(2):99-104.

8. Kang KS, YunJW, Yoon B, Lim YK, Lee YS. Preventive effect of germanium dioxide on the inhibition of gap junctional intercellular communication by TPA. Cancer Lett. 2001;166(2): 147-153.

9. Suzuki F, Brutkiewicz RR, Pollard RB. Ability of sera from mice treated with Ge-132, an organic germanium compound, to inhibit experimental murine ascites tumours. Br J Cancer. 1985; 52(5):757-763.

10. Han C, Wu G, Yin Y, Shen M. Inhibition by germanium oxide of the mutagenicity of cadmium chloride in various genotoxicity assays. Food Chem Toxicol. 1992;30(6):521-524.

11. Kada T, Mochizuki H, Miyao K. Antimutagenic effects of germanium oxide on Trp-P-2-induced frameshift mutations in Salmonella typhimurium TA98 and TA1538. Mutat. Res. 1984; 125(2):145-151.

12. Lee CH, Lin RH, Liu SH, Lin-Shiau SY. Effects of germanium oxide and other chemical compounds on phenylmercury acetate-induced genotoxicity in cultured human lymphocytes. Environ Mol Mutagen. 1998;31(2):157-162.

13. Aso H, Suzuki F, Yamaguchi T, Hayashi Y, Ebina T, Ishida N. Induction of interferon and activation of NK cells and macrophages in mice by oral administration of $\mathrm{Ge}-132$, an organic germanium compound. Microbiol Immunol. 1985;29(1):65-74.

14. Goodman S. Therapeutic effects of organic germanium. Med Hypotheses. 1988;26(3):207-215.

15. Ikemoto K, Kobayashi M, Fukumoto T, Morimatsu M, Pollard RB, Suzuki F. 2-Carboxyethylgermanium sesquioxide, a synthetic organogermanium compound, as an inducer of contrasuppressor T cells. Experientia. 1996;52(2):159-166.

16. Nakada Y, Kosaka T, Kuwabara M, Tanaka S, Sato K, Koide F. Effects of 2-carboxythylgerumanium sesquioxide (Ge-132) as an immunological modifier of post-surgical immunosuppression in dogs. J Vet Med Sci. 1993;55(5):795-799.

17. Nagata N, Yoneyama T, Yanagida K, Ushio K, Yanagihara S, Matsubara $\mathrm{O}$, et al. Accumulation of germanium in the tissues of a long-term user of germanium preparation died of acute renal failure. J Toxicol Sci. 1985;10(4):333-341.

18. Obara K, Saito T, Sato H, Yamakage K, Watanabe T, Kakizawa $\mathrm{M}$, et al. Germanium poisoning: clinical symptoms and renal damage caused by long-term intake of germanium. Jpn J Med. 1991;30(1):67-72.

19. Tao SH, Bolger PM. Hazard assessment of germanium supplements. Regul Toxicol Pharmacol. 1997;25(3):211-219.

20. Das SK, Masuda M, Sakurai A, Sakakibara M. Medicinal uses of the mushroom Cordyceps militaris: current state and prospects. Fitoterapia. 2010;81(8):961-968.

21. Gu Y X, Wang ZS, Li SX, Yuan QS. Effects of multiple factors on accumulation of nucleosides and bases in Cordyceps militaris. Food Chem. 2007;102(4):1304-1309.

22. Khan MA, Tania M, Zhang D, Chen H. Cordyceps mushroom: a potent anticancer nutraceutical. The Open Nutraceuticals Journal. 2010;3:179-183.

23. Mao XB, Eksriwong T, Chauvatcharin S, Zhong JJ. Optimization of carbon source/nitrogen ratio for cordycepin production by submerged cultivation of medicinal mushroom Cordyceps militaris. Process Biochem. 2005;40(5):1667-1672.

24. Won SY, Park EH. Anti-inflammatory and related pharmaco- 
logical activities of cultured mycelia and fruiting bodies of Cordyceps militaris. J Ethnopharmacol. 2005;96(3):555-561.

25. Dong JZ, Lei C, Ai XR, Wang Y. Selenium enrichment on Cordyceps militaris link and analysis on its main active components. Appl Biochem Biotechnol. 2012;166(5):1215-1224.
26. Shang D, Li Y, Wang C, Wang X, Yu Z, Fu X. A novel polysaccharide from Se-enriched Ganoderma lucidum induces apoptosis of human breast cancer cells. Oncol Rep. 2011; 25(1):267-272. 